\title{
Compositional and physical properties of camel milk under nomadic and sedentary production systems
}

\author{
Arab Khan Lund ${ }^{1 *}$, Tarique Ahmed Khokhar ${ }^{1}$, Aijaz Ali Junejo ${ }^{2}$, \\ Shahnawaz Kumbhar ${ }^{2}$, Qudratullah Kalwar' ${ }^{1}$, Yar Muhammad \\ Jalbani $^{1}$, Zafar Ali Khoso ${ }^{1}$, Muhammad Mohsen Rahimoon ${ }^{1}$, Abdul \\ Samad Mangsi ${ }^{1}$ and Asad Ali Khaskheli ${ }^{2}$ \\ 1. Shaheed Benazir Bhutto University of Veterinary and Animal Sciences, Sakrand-67210-Pakistan \\ 2. Sindh Agriculture University, Tandojam-Pakistan \\ *Corresponding author's email: $\underline{\text { aarabbaloch@gmail.com }}$ \\ Citation \\ Arab Khan Lund, Tarique Ahmed Khokhar, Aijaz Ali Junejo, Shahnawaz Kumbhar, Qudratullah Kalwar, Yar \\ Muhammad Jalbani, Zafar Ali Khoso, Muhammad Mohsen Rahimoon, Abdul Samad Mangsi and Asad Ali \\ Khaskheli. Compositional and physical properties of camel milk under nomadic and sedentary production \\ systems. Pure and Applied Biology. Vol. 8, Issue 2, pp1494-1498. http://dx.doi.org/10.19045/bspab.2019.80089

\begin{tabular}{llll}
\hline \hline Received: 05/02/2019 & Revised: 02/05/2019 & Accepted: 11/05/2019 & Online First: 17/05/2019 \\
\hline \hline
\end{tabular}

\section{Abstract}

Camel is considered as the best animal for arid and semiarid areas where its milk comprises a significant part of the human dietary habit. In the present study, unique composition of camel milk under nomadic and sedentary production system was investigated. Camel milk samples $(n=40)$ were collected from the nomadic $(n=20)$ and sedentary $(n=20)$ production system and analyzed for physical and chemical properties. The observation shows that the solid not fat content $(9.36 \%)$, lactose content $(4.77 \%)$, specific gravity (1.030), viscosity $(1.72 \mathrm{cP})$ and $\mathrm{pH}$ (6.60) were significantly $(\mathrm{P}<0.05)$ higher in the camel milk under sedentary production system in comparison to nomadic production system (i.e. solid not fat content $8.96 \%$, lactose content $4.45 \%$, specific gravity 1.028 , viscosity $1.60 \mathrm{cP}$ ) and $\mathrm{pH} 6.53)$. On the other hand, the fat content $(3.84 \%)$ and mineral content $(0.93 \%)$ were significantly $(\mathrm{P}<0.05)$ greater in the camel milk reared under nomadic production system than that of the sedentary production system (fat content $3.68 \%$ and mineral content $0.85 \%$ ). The total solids and protein content were increased in the milk of camel raised under the sedentary system, however, the variation was non-significant $(\mathrm{P}>0.05)$. It is concluded that the concentrated supplementation in sedentary production system has positive effects on the composition of camel milk. From a compositional point of views, the camel milk under sedentary production is superior over the camel milk under nomadic production system. It is recommended that farmers should provide the concentrate supplement to the camel under nomadic production system.

Keywords: Nomadic; Physicochemical; Production system; Sedentary \section{Introduction}

Pakistan is the rich source of agriculture and livestock. The livestock component contributed $11.11 \%$ to the gross domestic product (GDP) and $58.92 \%$ to the agriculture during the year 2017-2018. It is the estimated that approximately 8 million families involved in livestock which is central to the livelihood of the poor families in the country [1]. In livestock, camel (Camelus dromedarius) is the potential animal for the arid, mountainous and desert areas of our country and, therefore it plays the major role in the food 
security of these areas [2]. Pakistan is on the $8^{\text {th }}$ position in camel raising in the world population 24 million [3]. Camel has the capability to sustain their production under inclement weather. It is the only animal which can retain the lactation and secret milk with over 90\% water content even under dehydration condition [4].

In our country, the camels are raised under three production system as nomadic, sedentary and transhumant regarding topography, plant phonology, climatic conditions and water availability. The nomadic production system is well known for roaming of camels place to place because of the shortage of water and forages [2]. The sedentary production system is characterized by limited grazing and supplemented with concentrate ration. In this system, women play an important role by converting byproducts into valuable products and sell them in the market. In the transhumant production system, camel migrates on the basis of seasons especially rainfall. In this system animal sometimes migrates in specific places on scheduled periods of the year [5] There are various factors which influence the composition of camel milk ultimately cause the wide variation which are the calving number, age, management, sampling technique, lactation stage, feeding regime, and season [6]. The present study was designed to evaluate the effect of sedentary and nomadic production system on camel milk composition and physical properties in Sindh, Pakistan.

\section{Materials and methods \\ Study population}

In the present study, two groups were targeted for the collection of camel milk samples $(n=40)$. The first group was located at Tharparkar, Sindh $(n=20)$ where camel herders adapting nomadic production system and another group was selected at the pre-urban area of district Hyderabad $\quad(n=20)$ where sedentary production system is being practiced. She- camel of the first group totally depended on the grazing and browsing available plants and agriculture residue that grown naturally (uncultivated) without any supplements. While she-camels of the second group were allowed limited grazing in some time period on the day and provided cultivated grasses and concentrated supplements on the remaining time period of the day.

\section{Analysis of physical and chemical characteristics}

The samples $(n=40)$ were collected and brought (under $4 \pm 1^{\circ} \mathrm{C}$ ) to department of Animal Products Technology, Shaheed Benazir Bhutto University of Veterinary and Animal Sciences, Sakrand for physicochemical analysis.

\section{Physical properties}

The $\mathrm{pH}$, Viscosity, and Specific gravity were determined according to the standard methods [7, 8]. The following equipments, $\mathrm{pH}$ meter (Model-1 Hanna Instruments, Italy), Viscometer (Glass, Germany made) and Pycnometer (Glass, Germany made) were used.

\section{Chemical characteristics}

The chemical characteristics include lactose, total solid, solid not fat, protein, fat and mineral contents (\%) were determined according to the different standard methods [7-9]. Furthermore, procedures are briefly described below;

\section{Lactose, Total Solid and solid not fat contents (\%)}

Lactose, total solid and solid not fat contents (\%) were determined by the difference formula. Lactose content (\%) was obtained by deducting the summation of fat, protein and ash percentage from total solid content (\%) while total solid content $(\%)$ was evaluated by subtracting moisture percentage from 100. Solid not fat $(\%)$ was analyzed by subtracting the fat content $(\%)$ from total solid content $(\%)$ $[7,8]$.

\section{Protein content $(\%)$}

Camel milk sample (5g), copper sulphate $(0.2 \mathrm{~g})$, sodium sulphate $(2.0 \mathrm{~g})$ and concentrated sulfuric acid $(30 \mathrm{ml})$ were 
taken in kjeldahl flask and digested under micro-kjeldahl digester. The digested samples were diluted (with distal water), distilled (with sodium hydroxide $40 \%$ ) and titrated (with hydrochloric acid $0.1 \mathrm{~N}$ ) according to the method of British Standards Institution [10].

\section{Fat content (\%)}

Fat content was analyzed according to the Gerber method. $90 \%$ sulfuric acid $(10 \mathrm{ml})$, camel milk sample $(11 \mathrm{ml})$ and amyl alcohol (1ml) were added in the butyrometer and closed tightly with stopper. The butyrometer placed in the Gerber centrifuge machine and centrifuged for $3 \mathrm{~min}$ at $1100 \mathrm{rpm}$ [9].

\section{Mineral or ash contents (\%)}

Camel milk sample $(5 \mathrm{~g})$ was taken on the crucible dish and dried in the muffle furnace $\left(550^{\circ} \mathrm{C}\right)$ for $4 \pm 1$ hours and then transferred to desiccator for 1 hour and calculation was made according to the method described in Association of Official Analytical Chemistry (AOAC) [8].

\section{Statistical analysis}

The computer program (Statistix SXW, Version 8.1 copyright 2005, Analytical software, USA) was used for the analysis of collected data. The analysis of variance (AOV) and least significant difference (LSD) procedure were used to find the variation in between the data of nomadic and sedentary production system.

\section{Results and discussion}

\section{Chemical characteristics}

The results of the chemical analysis of nomadic and sedentary production system are presented in table 1. The findings of the present study showed that the lactose and solid not fat contents were significantly $\quad(\mathrm{P}<0.05) \quad$ higher in comparison to the nomadic production system. The variation might be due to different feeding and management system. Furthermore, in the sedentary production system, she-camels were offered a supplement of concentration that also altered the composition of milk. These results are supported by the findings of $[11,12]$. On the other hand, fat and mineral content observed higher under the nomadic production system than the sedentary system. Statistically, the variation was significant $(\mathrm{P}<0.05)$ between nomadic and sedentary production system. This significant difference because of shecamel in nomadic production system depends totally on grazing without any concentration supplements that enhance the concentration of fatty acid and minerals as plants are the rich source of these. No doubt, Alwan and Zwaik [13] found the wide range variation in the milk components because of management and feeding difference among various production system. Yagil, [4] reported that the water intake of camel different under different production system which affects the feed intake result in the variation of chemical composition.

The total solids and protein contents of camel milk were slightly higher under sedentary than that of the nomadic production system. The statistical analysis shows that the difference was not significant $(\mathrm{P}>0.05)$ in between nomadic and sedentary production system. These findings are somewhat different than the findings of $[6,12]$, who found the significant $(\mathrm{P}<0.05)$ difference in protein and total solid contents, respectively. However, the results are in a positive relationship with the observation of [11] and within range of camel milk composition reported by $[14,15]$. 
Table 1. Chemical composition of camel milk under nomadic and sedentary production systems

\begin{tabular}{|c|c|c|c|c|}
\hline \multirow{2}{*}{ Milk Constituents (\%) } & \multicolumn{2}{|c|}{ Production systems } & \multirow{2}{*}{ SE \pm} & \multirow{2}{*}{ LSD (0.05) } \\
\cline { 2 - 3 } & Nomadic & Sedentary & 0.0818 & 0.1656 \\
\hline Fat content & $3.84^{\mathrm{a}}$ & $3.68^{\mathrm{b}}$ & 0.0818 & 0.1742 \\
\hline Protein content & $3.58^{\mathrm{a}}$ & $3.73^{\mathrm{a}}$ & 0.0860 & 0.1967 \\
\hline Lactose content & $4.45^{\mathrm{b}}$ & $4.77^{\mathrm{a}}$ & 0.0971 & 0.0296 \\
\hline Mineral content & $0.93^{\mathrm{a}}$ & $0.85^{\mathrm{b}}$ & 0.0298 \\
\hline Solid not fat (SNF) & $8.96^{\mathrm{b}}$ & $9.36^{\mathrm{a}}$ & 0.1284 & 0.2599 \\
\hline Total solid (TS) & $12.81^{\mathrm{a}}$ & $13.04^{\mathrm{a}}$ & 0.1668 & 0.3376 \\
\hline
\end{tabular}

Values with different superscripts show significant difference

\section{Physical characteristics}

The physical properties of camel milk under different production systems are given in table 2. Like to the chemical characteristics, the physical properties are varied under nomadic and sedentary production systems. The specific gravity, viscosity and $\mathrm{pH}$ significantly $(\mathrm{P}<0.05)$ higher in the camel milk under sedentary production system that of the nomadic production system. Baloch et al., [16] reported that physical properties vary with the feeding, management and climatic condition. It is of interest to note that the specific gravity and viscosity are directly related to the total solid that's why they increased in the sedentary production system as total solid increased in the camel milk under sedentary production system. The variation in $\mathrm{pH}$ of camel milk under two production systems is because of the difference of mineral contents which alter the hydrogen ion concentration. Furthermore, present findings are within the range of $[17,18]$.

Table 2. Physical characteristics of camel milk under nomadic and sedentary production systems

\begin{tabular}{|c|c|c|c|c|}
\hline \multirow[b]{2}{*}{ Physical characteristics } & \multicolumn{2}{|c|}{ Production systems } & \multirow[b]{2}{*}{ SE } & \multirow[b]{2}{*}{ LSD } \\
\hline & Nomadic & Sedentary & & \\
\hline Specific Gravity & $1.028^{\mathrm{b}}$ & $1.030^{\mathrm{a}}$ & 0.0003796 & 0.0007684 \\
\hline Viscosity (cP) & $1.60^{\mathrm{b}}$ & $1.72^{\mathrm{a}}$ & 0.0373 & 0.0756 \\
\hline $\mathrm{pH}$ & $6.53^{\mathrm{b}}$ & $6.60^{\mathrm{a}}$ & 0.0199 & 0.0403 \\
\hline
\end{tabular}

Values with different superscripts show significant difference

\section{Conclusion}

It could be concluded that the production system influence the chemical and physical properties of camel milk. The composition of camel milk was varied in the camel milk of nomadic production than that of the sedentary production system. Sedentary production system showed a positive effect in constituents of camel milk by improving its total solid contents.

\section{Authors' contributions}

Conceived and designed the experiments: AK Lund, TA Khokhar, Q Kalwar \& AA Khaskheli, Performed the experiments: AK Lund, Analyzed the data: AK Lund, S Kumbhar, AS Mangsi \& AA Junejo,
Contributed materials/ analysis/ tools: MM Rahimoon, ZA Khoso \& YM Jalbani, Wrote the paper: AK Lund.

\section{References}

1. Economic Survey of Pakistan (20172018). Economic Advisor's Wing, Finance Division, Government of Pakistan, Islamabad, Pakistan.

2. Faraz A, Mustafa MI, Lateef M, Yaqoob M \& Younas M (2013). Production potential of camel and its prospects in Pakistan. Punjab Uni J Zool 28(2): 89-95.

3. Food and Agriculture Organization (2010). FAOSTAT. FAO statistics division 2013 | 05 January 2013. 
4. Yagil R (1982). Camels and camel milk Animal production and health report. FAO. Rome, Italy.

5. Ahmad S, Yaqoob M, Hashmi N, Ahmad S, Zaman MA \& Tariq M (2010). Economic importance of camel: a unique alternative under crisis. Pak Vet J 30(4): 191-197.

6. Shuiep ES, El Zubeir IEM, El Owni OAO \& Musa HH (2008). Influence of season and management on composition of raw camel (Camelusdromedarius) milk in Khartoum state, Sudan. Tropical and subtropical Agroecosystems 8(1): 101106.

7. Association of official analytical chemistry (1990c). Dairy products. In: official Methods of Analysis. Association of Official Analytical Chemists (AOAC), Inc. Gaithersburg, USA.

8. Association of official analytical chemistry (2000). Dairy products. In: official Methods of Analysis. Association of Official Analytical Chemists (AOAC), Inc. Gaithersburg, USA.

9. James CS (1995). Determination of fat content dairy products by the gerber method. In: Analytical Chemistry of foods, ( $5^{\text {th }}$ revised edition). London: Royal Society of Chemistry and Ministry of Agriculture, Fisheries and Foods 5: 18-94.

10. British Standards Institution (1990). Determination of nitrogen content of liquid milk In: Methods of chemical Analysis of liquid milk and cream. BSI: 1741, British Standards Institution (BSI), London, UK.

11. El-Malky OM, AM AES \& Nabih AM (2017). Some Studies on Milk
Production and its Composition In Maghrebi She-Camel Under Farming And Traditional Pastoral Systems In Egypt.

12. Shuiep ETS, El Zubeir EM \& Yousif IA (2014). Compositional quality of camel milk and some husbandry practices associated with camel milk production in two production systems in Sudan.

13. Alwan OA \& Zwaik HB (2014). Milk composition of Libyan Maghrebi camels (Camels Dromedaries) reared under farm and desert conditions. In International Conference on Chemical and Environment and Biological Science. Malaysia, pp 1718.

14. Konuspayeva G, Faye B \& Loiseau G (2009). The composition of camel milk: a meta-analysis of the literature data. $J$ of Food Compos and Anal 22(2): 95-101.

15. Khan BB \& Iqbal A (2001). Production and composition of camel milk. Review. Pak J of Agri Sci 38: 64-68.

16. Baloch MH, Shah AH, Nizamani ZA, Rajput MN \& Magsi H (2018). 26. Physico-chemical and sensorial variation in camel milk produced at different zones of Sindh, Pakistan. Pure and Appl Biol 7(2): 625-634.

17. Iqbal A, Gill RA \& Younas M (2001). Milk composition of Pakistani camel (Camelus dromedaries) kept under station/farmer's conditions. Emirates $J$ of Food and Agri 7-10.

18. EI-Erian AFM (1979). Studies on camel milk in the Kingdom of Saudi Arabia. In Proc. 2nd Arab Conf. Food Sci. Technol., Saudi Arabia. 